Available online at GSC Online Press Directory

GSC Biological and Pharmaceutical Sciences

e-ISSN: 2581-3250, CODEN (USA): GBPSC2

Journal homepage: https://www.gsconlinepress.com/journals/gscbps

(RESEARCH ARTICLE)

\title{
Plant growth promotion effects of rhizopheric and endophytic bacteria on sugarcane cultivated on Acrisols of Tay Ninh province, Vietnam
}

\author{
Hoang Minh Tam ${ }^{1, *}$ and Cao Ngoc Diep ${ }^{2}$ \\ ${ }^{1}$ Department of Natural Science Teacher Training, Sai Gon University, Ho Chi Minh City, Vietnam. \\ 2 Dept. Microbiology Biotechnology, Biotechnology R\&D Institute, Can Tho University, Can Tho City, Vietnam.
}

Publication history: Received on 16 December 2020; revised on 23 December 2020; accepted on 25 December 2020

Article DOI: https://doi.org/10.30574/gscbps.2020.13.3.0408

\begin{abstract}
Plant growth promotion of the best two strains: Serratia oryzae CT4b and Bacillus subtilis TPD3b together with chemical nitrogen and phosphorus fertilizers were continuously evaluated on sugarcane cultivated on Acrisols of Tay Ninh province, Vietnam in pots and field experiments. The experiments were arranged into a Split-Plot Design with four replications. The main plot factor was N-P fertilizer at five levels: without N-P, 25\% N-P, 50\% N-P, 75\% N-P and 100\% $\mathrm{N}-\mathrm{P}$ for the pot experiment and at four levels: without N-P; $50 \% \mathrm{~N}-\mathrm{P} ; 75 \% \mathrm{~N}-\mathrm{P}$; and 100\% N-P for the field experiment. The sub-plot factor was bacterial inoculation with 4 treatments: no bacteria; CT4bd; TPD3b; and mixture of both. Recommended amount of nitrogen and phosphorus fertilizers for sugarcane planted on Acrisols of Tay Ninh province were $200 \mathrm{~kg} \mathrm{~N}, 160 \mathrm{~kg} \mathrm{P}_{2} \mathrm{O}_{5}$ in a hectare. The results showed that a combination of two bacteria had the highest plant growth stimulation potential. The mixture at rate of $75 \% \mathrm{~N}$ - P fertilizers produced sugarcane yield equal to that at level of $100 \% \mathrm{~N}-\mathrm{P}$ fertilizer without bacteria in the pot experiment; increased sugar yield by $14.4 \%$, equivalent to 1.02 ton / ha in the field trial and saved $25 \%$ of N-P fertilizer application. These two potential strains were proposed to be tested their ability to promote plant growth on many different sugarcane varieties in both plant-cane and ratoon crops in different material sugarcane areas of Tay Ninh province.
\end{abstract}

Keywords: Acrisol; Plant growth promotion; Soil fertility; Sugarcane; Sugar yield

\section{Introduction}

Sugarcane was cultivated in over 110 tropical and subtropical countries in which Brazil and India occupied 50 percent of global production. In growth and development, sugarcane required a massive amount of nutrients. Together with other essential elements, phosphorus, nitrogen were vital precursors for a lot of biosynthesizes such as photosynthesis and amino acid synthesis and nitrogen, an important yield limiting factor was sufficiently applied [1].

In order to maximize yields and sucrose component, sugarcane producers often applied high rates of nitrogen (N) fertilizer. While $\mathrm{N}$ fertilizer used for one hectare was in the range of from 120 to $300 \mathrm{~kg}$. In average, crops only used 50 per cent of $\mathrm{N}$ fertilizer applied [2]. There were many reasons for the low fertilizer use efficiency such as high soil nitrification rates and $\mathrm{N}$ leaching and denitrification by weather extremes [3]. Excessive use of $\mathrm{N}$ fertilizers increased production costs and caused negative effects on environment and human health.

One of various methods of increasing sugarcane yield, available soil nitrogen, applied fertilizers but low production cost was the use of microorganisms capable of promoting crop growth [4]. Field studies of inoculant efficiency reported that diazotrophic bacteria increased stem and dry matter yield of various sugarcane varieties. These bacteria concluded

\footnotetext{
* Corresponding author: Hoang Minh Tam

Sai Gon University, 273 An Duong Vuong, Ward 3, District 5, Ho Chi Minh City, Vietnam.
} 
endophytic and rhizopheric bacteria. There were physical, chemical and biological differences in endophytic and rhizospheric environments. Thus, different bacterial communities grew at each site. However, bacteria could colonize both within plants and in the rihzospheric soil such as Enterobacteria [5]. Mechanisms of their plant growth promoting activities were similar and involved in capacities of biological nitrogen fixation, mineral solubilization, plant phytohormone production and pathogen biocontrol [6]. Besides these, endophytic and rihzopheric bacteria could benefit the sugarcane through other mechanisms that promoted availability and uptake of mineral nutrients [7]. Specially, colonization of endophytic and rhizopheric bacteria did not provoke any host plant defense [2].

The aims of the present study were to evaluate efficiency of two indigenous bacteria strains isolated from sugarcane cultivated in Tay Ninh Province, Vietnam with the best in vitro plant growth promotion on agronomic properties and yields of sugarcane planted Tay Ninh province, Vietnam. Up to now, this was the first investigation of a natural association between indigenous plant growth promoting bacteria and sugarcane in Vietnam.

\section{Material and methods}

\subsection{Experiment site}

The experiments were conducted at C1-TSX Experimental Station, Thanh Thanh Cong Sugarcane Research and Development Center (SRDC), 99 Binh Hoa, Chau Thanh district, Tay Ninh province in Vietnam from April 2019 to March, 2020. The Acrisols were nutrient - poor soils with pH 6.05; total N 0.058\%; available P 112.52 ppm and total organic matter $1.47 \%$.

\subsection{Bacterial isolates and bacterial preparation}

Two bacterial strains used in this study were Serratia oryzae Serratia oryzae CT4bd, an endophytic bacterium of local sugarcane and Bacillus subtilis Bacillus subtilis TPD3b, a rhizopheric bacterium of local sugarcane evaluated the best efficiency on in vitro in vitro plant growth promotion $[8,9,10]$. The bacterial strains were separately prepared by growing in LG media at $28 \pm 2{ }^{\circ} \mathrm{C}$ for 48 hours. Bacterial cell suspensions had density of approximately $1.5 \times 10^{8} \mathrm{CFU}$ $\mathrm{mL}^{-1}$, corresponding to 0.5 of McFarland Turbidity Standard [11].

\subsection{Sugarcane cuttings}

Trial sugarcane in this study was Saccharum officium L. var K95-156, supplied by Thanh Thanh Cong Sugarcane Research and Development Center was used. Six-months old cuttings with three good offsets without disease signals were used.

\subsection{Inoculation of sugarcane cuttings with bacterial suspensions}

The sugarcane cuttings were completely immersed in basins with $200 \mathrm{~L}$ inoculum with $1.5 \times 10^{6} \mathrm{CFU} \mathrm{mL}^{-1}$ of Serratia oryzae CT4bd or Bacillus subtilis TPD3b or their combination. For the control treatment, sugarcane cuttings were immersed in basins of 200L water without the bacteria. Inoculating time was about two hours [1].

\subsection{Pot-experiment}

Sugarcane inoculated and control cuttings were put in plastic containers $\left(40 \times 30 \times 20 \mathrm{~cm}^{3}\right)$ with $20 \mathrm{dm}^{3}$ Acrisol soil which was taken from Experimental Station of the Thanh Thanh Cong Sugarcane Research and Development Center, and covered with a soil layer of $2-3 \mathrm{~cm}$.

The experiment was arranged into a Split-Plot Design [12] with 5 blocks. Each block was separate about $15 \mathrm{~cm}$ apart and contained 4 main plots. One main plots consisted of 4 subplots. The main plot factor was fertilizer (N-P) at five levels: F0 without N and P; F1 with 25\% N and 25\% P; F2 with 50\% N and 50\% P; F3 with 75\% N and 75\% P; and F4 with $100 \% \mathrm{~N}$ and $100 \% \mathrm{P}$. The sub-plot factor was bacterial inoculation with 4 treatments: (B0): no bacteria; (B1): Serratia oryzae CT4bd; (B2): Bacillus subtilis TPD3b; (B3): mixture of Serratia oryzae CT4bd and Bacillus subtilis TPD3b. The experiment was conducted with four replications. The experiment had total of 80 pots placed with distance between two pots about $30 \times 10 \mathrm{~cm}$ (Figure).

Inorganic N-P-K fertilizers applied for sugarcane were recommended by Thanh Thanh Cong Sugarcane Research and Development Center as follows: $200 \mathrm{~kg} \mathrm{~N}, 160 \mathrm{~kg} \mathrm{P}_{2} \mathrm{O}_{5}, 240 \mathrm{~kg} \mathrm{~K}_{2} \mathrm{O}$ in a hectare of sugarcane planted on the Acrisol soil. Fertilizer application was divided three times. Basal fertilization was applied with whole phosphorous fertilizer (100\%), 1/3 nitrogen fertilizer, and $1 / 3$ potassium fertilizer. The first top dressing fertilization was carried out with $1 / 3$ nitrogen fertilizer and $1 / 3$ potassium fertilizer when sugarcane plants with 3-4 leaves were one and a half months 
old. The remained nitrogen and potassium fertilizer were fertilized sugarcane plants when they had 9-10 leaves and were four-five months old. Watering for sugarcane plants was carried out two-three times per week. Other cares for sugarcane were followed recommendations of Thanh Thanh Cong Sugarcane Research and Development Center.

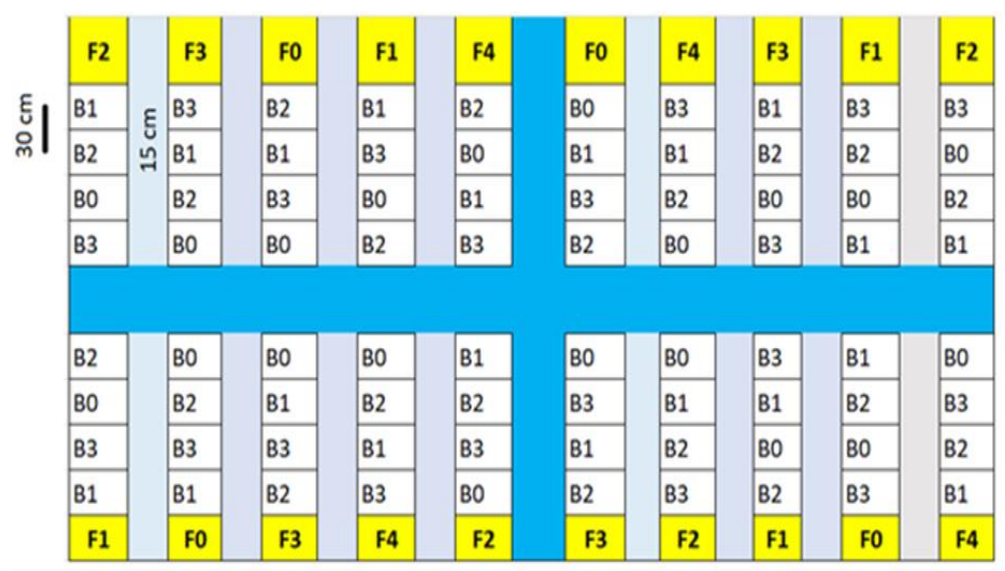

Figure 1 Experiment diagram of the pot-experiment with 4 replications and total number of 80 pots

(F0): without N, P; (F1): 25\% N [50 kg N / ha] and 25\% P [40 kg $\mathrm{P}_{2} \mathrm{O}_{5} / \mathrm{ha}$ ]; (F2): $50 \% \mathrm{~N}$ [100 kg N / ha] and $50 \% \mathrm{P}$ [80 kg $\mathrm{P}_{2} \mathrm{O}_{5}$ / ha]; (F3):75\% N [150 kg N / ha] and 75\% P [120 kg P2O5 / ha]; (F4) 100\% N [200 kg N / ha] and 100\% P. [160 kg $\mathrm{P}_{2} \mathrm{O}_{5}$ / ha]; (B0):no inoculation; (B1): Serratia oryzae CT4bd; (B2); Bacillus subtilis TPD3b; (B3): mixture of Serratia oryzae CT4bd and Bacillus subtilis TPD3b

After180 days of planting, sugarcane plants were harvested to measure plant height with a tape measure, diameter of stem with a caliper at middle tree $(\mathrm{cm})$, count number of internodes, measure degree Brix with Hand Refractometer and calculate commercial cane sugar CCS (\%) $\left(^{*}\right)$, stalk yield (ton/ha) and sugar yield (CCS\% x stalk yield). Through these criteria, PGPB's effects on sugarcane planted in post were evaluated.

$$
\operatorname{ccs}(\%)=\frac{\mathrm{Bx}_{g \delta c}+B x_{n g o n}}{2} \times 0,66-3,5{ }^{(*)}
$$

\subsection{Field Experiment}

The experiment was arranged into a Split-Plot Design [12]. The experiment area was divided into 4 blocks. Each block was separate about $1.5 \mathrm{~m}$ apart and contained 4 main plots. One main plot consisted of 4 subplots. Area of one subplot was $42 \mathrm{~m}^{2}\left(15 \times 2.8 \mathrm{~m}^{2}\right)$ (Figure 2).

The main plot factor was fertilizer (N-P) with 4 levels: F0 without N and P; F1 with 50\% N [100 kg N/ha] and 50\% P [80 $\mathrm{kg} \mathrm{P}_{2} \mathrm{O}_{5}$ / ha]; F2 with 75\% N [150 kg N / ha] and 75\% P [120 kg P $\mathrm{O}_{5} / \mathrm{ha}$ ] and F3 100\% N [200 kg N / ha] and 100\% P [160 kg $\mathrm{P}_{2} \mathrm{O}_{5} / \mathrm{ha}$ ]. The subplot factor was bacterial inoculation with 4 treatments: B0 with no bacteria; B1with Serratia oryzae CT4bd; B2 with Bacillus subtilis TPD3b; and B3 with mixture of Serratia oryzae CT4bd and Bacillus subtilis TPD3b. Each treatment was with 4 replications.

Soil preparation contained steps of ploughing, harrowing and furrowing. Depth of furrows was $30 \mathrm{~cm}$. The furrow bottom was loosened to about $10 \mathrm{~cm}$. Each subplot consisted of two furrows. The sugarcane inoculated and control cuttings were put down the furrows and covered with a $2-3 \mathrm{~cm}$ soil layer. Procedure of fertilization, watering and other cares for sugarcane were carried out as in the pot experiment.

The sugarcane plants were harvested after 12 months of planting. Evaluations of plant growth promotion bacteria's effect on sugarcane were carried out through stem height $(\mathrm{cm})$, stem diameter $(\mathrm{cm})$, number of internodes, degree Brix (\%), CCS (\%), stem yield (ton / ha) and sugar yield (ton / ha). 


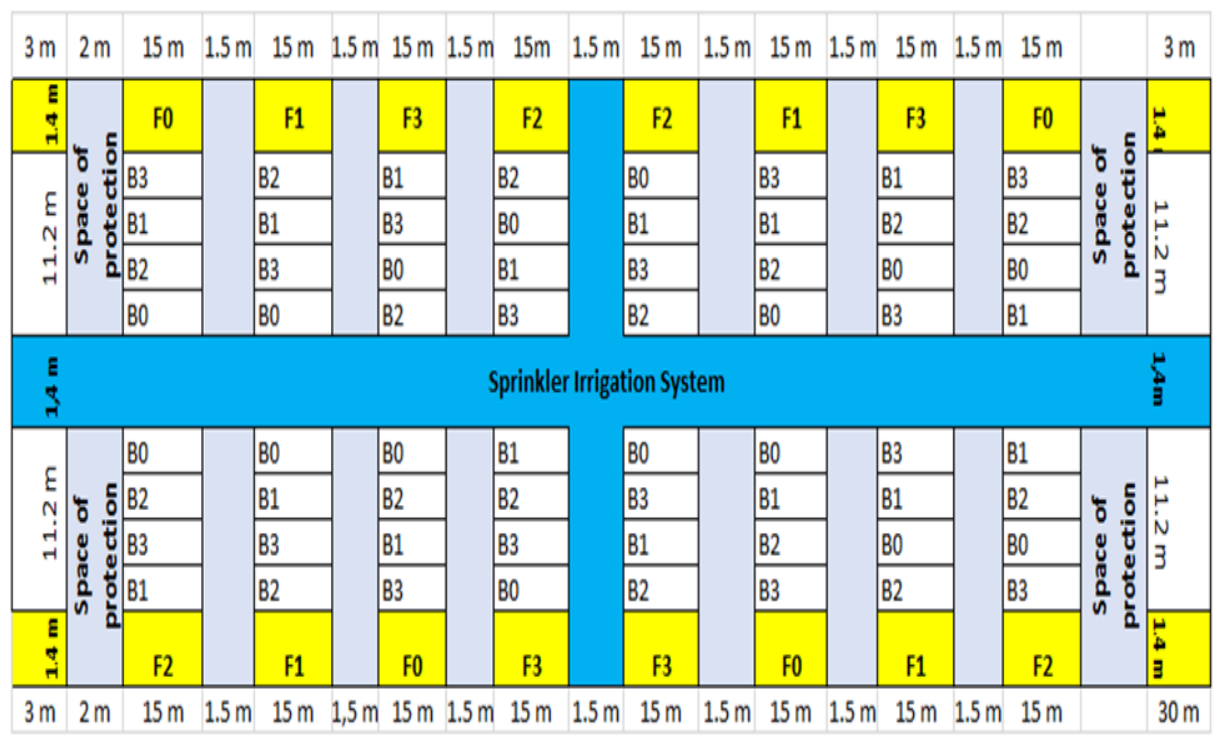

Figure 2 Field Experimental diagram with 4 replications and total number of 64 plots

(F0): without N, P; (F1): 50\% N [100 kg N/ha] and 50\% P [80 kg P2O5/ha]; (F2):75\% N [150 kg N/ha] and 75\% P [120 kg $\mathrm{P}_{2} \mathrm{O}_{5}$ / ha]; (F3) 100\% N [200 kg N / ha] and 100\% P. [160 kg $\mathrm{P}_{2} \mathrm{O}_{5}$ / ha]; (B0):no inoculation; (B1): Serratia oryzae CT4bd; (B2); Bacillus subtilis TPD3b; (B3): mixture of Serratia oryzae CT4bd and Bacillus subtilis TPD3b

\subsection{Statistical analysis}

Data for the pot and field experiments was analyzed by using Two-way ANOVA for Split-Plot Design and comparisons of means were carried out based on LSD test at $5 \%$ level of confidence.

\section{Results and discussion}

\subsection{Pot-experiment}

The results from Table 1 and 3; Figure: 4 and 5 showed that treatments that did not use bacteria and combined $\mathrm{N}$ and $\mathrm{P}$ fertilization levels from $0 \%$ to $100 \%$ (B0F0, B0F1, B0F2, B0F3, B0F4) enhanced all most monitoring indicators including internode number, stem height, stem diameter, stalk yield, degree Brix, CCS, and sugar yield. These indicated vital role of chemical fertilizers for crops in general, as well as the role of chemical N, P fertilizers in the growth and yield of sugarcane.

Regarding the role of bacteria in promoting plant growth (Table 1), compared with the treatments without bacteria inoculation and fertilizers (the negative control - B0F0), all treatments used CT4bd, TPD3b separately or together (B1F0, B2F0, B3F0) all gave better results. This show that the two strains of tested bacteria had positive effects on growth criteria and yields of sugarcane.

For the growth indicators (Table 1), including internode number, stem height and stem diameter, most of the treatments combining each bacteria strain and levels of chemical fertilizers showed lower results than the treatment of $100 \%$ chemical N, P fertilizer and no bacteria (the positive control - B0F4). However, using TPD3b isolate in combination with level of 75\% N, P fertilizers (treatment B2F3) increased the number of internodes by 5.9\% compared with the positive control. Applying CT4bd isolate in combination with N, P fertilizer at all rates of fertilization increased stem diameter compared with the positive control. In particular, CT4bd with 75-100\% N, P (treatment B1F4) increased stem diameter by $1.36-13.6 \%$. 
Table 1 Effects of two strains and nitrogen and phosphorus fertilizers on the yield component of sugarcane (K95-156 cultivar) cultivated on Acrisols in the pot experiment.

\begin{tabular}{|c|c|c|c|}
\hline Treatment & Plant height (cm) & $\begin{array}{l}\text { Diameter of } \\
\text { stalk (cm) }\end{array}$ & $\begin{array}{l}\text { Number of } \\
\text { internodes/plant }\end{array}$ \\
\hline O N-P no inoculation (B0F0) & $58.75^{\mathrm{i}}$ & $1.99 \mathrm{~h}$ & $9.00^{\mathrm{h}}$ \\
\hline $25 \%$ N-P no inoculation (B0F1) & $87.50 \mathrm{bcd}$ & $2.42 \mathrm{acb}$ & $10.13 \mathrm{fg}$ \\
\hline $50 \%$ N-P no inoculation (B0F2) & 86.50 cde & $2.18 \mathrm{fg}$ & 10.13 fg \\
\hline 75\% N-P no inoculation (B0F3) & 84.50 def & 2.40 a-d & $12.13 \mathrm{bcd}$ \\
\hline $100 \%$ N-P no inoculation (B0F4) & $90.50 \mathrm{bcd}$ & 2.20 efg & 11.88 b-e \\
\hline Serratia oryzae CT4bd + 0 NP (B1F0) & $80.25^{d-h}$ & $2.24^{\mathrm{c}-\mathrm{g}}$ & $9.88 \mathrm{gh}$ \\
\hline Serratia oryzae CT4bd + 25\% N-P (B1F1) & $71.25 \mathrm{gh}$ & $2.33 \mathrm{~b}-\mathrm{f}$ & 11.88 b-e \\
\hline Serratia oryzae CT4bd + 50\% N-P (B1F2) & $98.50 \mathrm{ab}$ & $2.45^{a b}$ & $12.75 \mathrm{ab}$ \\
\hline Serratia oryzae CT4bd + 75\% N-P (B1F3) & $73.25 \mathrm{fgh}$ & $2.23 \mathrm{~d}-\mathrm{g}$ & 11.50 cde \\
\hline Serratia oryzae CT4bd + 100\% N-P (B1F4) & $80.50^{d-h}$ & $2.50 \mathrm{ab}$ & 11.13 e \\
\hline Bacillus subtilis TPD3b + 0 NP (B2F0) & $70.25^{h}$ & $2.10 \mathrm{gh}$ & $10.00 \mathrm{~g}$ \\
\hline Bacillus subtilis TPD3b + 25\% N-P (B2F1) & $88.75 \mathrm{bcd}$ & $2.16 \mathrm{fgh}$ & $12.25 \mathrm{bcd}$ \\
\hline Bacillus subtilis TPD3b + 50\% N-P (B2F2) & $71.75 \mathrm{gh}$ & 2.13 gh & 11.00 ef \\
\hline Bacillus subtilis TPD3b + 75\% N-P (B2F3) & $94.00 \mathrm{bc}$ & $2.50 \mathrm{ab}$ & $12.50 \mathrm{ab}$ \\
\hline Bacillus subtilis TPD3b + 100\% N-P (B2F4) & 87.25 b-e & $2.38 \mathrm{a}-\mathrm{e}$ & $12.50 \mathrm{ab}$ \\
\hline S. oryzae CT4bd + B. subtilis TPD3b + 0 NP (B3F0) & $82.00 \mathrm{~d}-\mathrm{g}$ & 2.20 efg & $10.13 \mathrm{fg}$ \\
\hline S. oryzae CT4bd + B. subtilis TPD3b $+25 \%$ N-P (B1F1) & 76.00 e-h & $2.18 \mathrm{fg}$ & $12.38 \mathrm{abc}$ \\
\hline S. oryzae CT4bd + B. subtilis TPD3b + 50\% N-P (B1F2) & $80.00 \mathrm{~d}-\mathrm{h}$ & $2.23 \mathrm{~d}-\mathrm{g}$ & 11.38 de \\
\hline S. oryzae CT4bd + B. subtilis TPD3b + 75\% N-P (B1F3) & 109.50 a & $2.54^{\mathrm{a}}$ & 13.50 a \\
\hline S. oryzae CT4bd + B. subtilis TPD3b $+100 \%$ N-P (B1F4) & $116.25^{a}$ & $2.60^{\mathrm{a}}$ & $13.25^{\mathrm{a}}$ \\
\hline $\mathrm{CV} \%$ & 11.75 & 6.73 & 6.7 \\
\hline
\end{tabular}

Numbers following the same word not difference at $5 \%$ level

With regard to degree Brix and CCS (Table 2), CT4bd in combination with N, P fertilizers at 25-50\% (B1F1 and B1F2), achieved results lower than that of the positive control. However, CT4bd (B1F3) at 75\% N, P fertilizers increased the degree Brix and CCS by $1.54 \%$ and 1.02\% compared with the positive control B0F4 respectively. Particularly, the TPD3b at $25-50 \%$ of $\mathrm{N}$, P fertilizers (treatments B2F1 and B2F2) increased the degree Brix and CCS by $0.08-0.31 \%$ and $0,05-$ $0.2 \%$ compared with the positive control respectively. 
Table 2 Effects of two strains and nitrogen and phosphorus on the degree Brix, and CCS of sugarcane (K95-156 cultivar) cultivated on Acrisols in the pot experiment

\begin{tabular}{|c|c|c|}
\hline Treatment & Degree Brixz (\%) & CCS (\%) \\
\hline O N-P no inoculation (B0F0) & $14.82^{\mathrm{hi}}$ & $6.28 \mathrm{hi}$ \\
\hline $25 \%$ N-P no inoculation (B0F1) & $15.76^{\mathrm{c}-\mathrm{h}}$ & $6.90^{c-g}$ \\
\hline $50 \%$ N-P no inoculation (B0F2) & $15.02^{\mathrm{f}-\mathrm{i}}$ & $6.41^{\mathrm{f}-\mathrm{i}}$ \\
\hline 75\% N-P no inoculation (B0F3) & $15.47 \mathrm{~d}-\mathrm{h}$ & $6.71^{\mathrm{d}-\mathrm{h}}$ \\
\hline $100 \%$ N-P no inoculation (B0F4) & $15.688^{c-h}$ & $6.85^{\mathrm{c}-\mathrm{h}}$ \\
\hline Serratia oryzae CT4bd + 0 NP (B1F0) & $15.60 \mathrm{c-h}$ & $6.80 \mathrm{ch}$ \\
\hline Serratia oryzae CT4bd + 25\% N-P (B1F1) & 14.75 hi & $6.24 \mathrm{hi}$ \\
\hline Serratia oryzae CT4bd $+50 \%$ N-P (B1F2) & 14.85 ghi & 6.30 ghi \\
\hline Serratia oryzae CT4bd + 75\% N-P (B1F3) & $17.22^{\mathrm{a}}$ & 7.87 a \\
\hline Serratia oryzae CT4bd + 100\% N-P (B1F4) & $14.50^{\mathrm{i}}$ & $6.07^{\mathrm{i}}$ \\
\hline Bacillus subtilis TPD3b + 0 NP (B2F0) & $17.02 \mathrm{ab}$ & $7.73 \mathrm{ab}$ \\
\hline Bacillus subtilis TPD3b + 25\% N-P (B2F1) & $15.76^{\mathrm{c}-\mathrm{h}}$ & $6.90^{c-g}$ \\
\hline Bacillus subtilis TPD3b + 50\% N-P (B2F2) & 15.99 cde & 7.05 cde \\
\hline Bacillus subtilis TPD3b + 75\% N-P (B2F3) & $15.15^{\mathrm{e}-\mathrm{i}}$ & $6.50^{\mathrm{e}-\mathrm{i}}$ \\
\hline Bacillus subtilis TPD3b + 100\% N-P (B2F4) & $15.93 \mathrm{c-f}$ & $7.01^{\mathrm{c}-\mathrm{f}}$ \\
\hline S. oryzae CT4bd + B. subtilis TPD3b + 0 NP (B3F0) & $16.14 \mathrm{bcd}$ & $7.15 \mathrm{bcd}$ \\
\hline S. oryzae CT4bd + B. subtilis TPD3b + 25\% N-P (B1F1) & $16.41 \mathrm{abc}$ & $7.33 \mathrm{abc}$ \\
\hline S. oryzae CT4bd + B. subtilis TPD3b + 50\% N-P (B1F2) & $15.61^{\mathrm{c}-\mathrm{h}}$ & $6.80 \mathrm{c}-\mathrm{h}$ \\
\hline S. oryzae CT4bd + B. subtilis TPD3b + 75\% N-P (B1F3) & $17.37^{\text {a }}$ & $7.96^{\mathrm{a}}$ \\
\hline S. oryzae CT4bd + B. subtilis TPD3b $+100 \%$ N-P (B1F4) & $15.36^{\mathrm{d}-\mathrm{i}}$ & $6.64 \mathrm{~d}-\mathrm{i}$ \\
\hline CV \% & 5.15 & 7.78 \\
\hline
\end{tabular}

Combination of two strains CT4bd and TPD3b (B3F0), compared with the negative control, enhanced the growth and yields of sugarcane about $12.6 \%$ of internode numbers, $39.6 \%$ of stem height, $9.5 \%$ of stem diameter (Table 1 ), $75 \%$ of cane yield (Figure 3), $0.09 \%$ of degree Brix, 13,9\% of CCS (Table 2) and 101.4\% of sugar yield (Figure 4). In particular, for all criteria, the combination of two strains CT4bd and TPD3b with 75\% of fertilizer N, P (B3F3) gave the best results: increased $13.6 \%$ of number of internodes, $21 \%$ of the body height, $15.5 \%$ of stem diameter (Table 1 ), $4.6 \%$ of sugarcane yield (Figure 3), 10.8\% of degree Brix, $16.2 \%$ of CCS (Table 2) and $21.7 \%$ of sugar yield (Figure 4 ), compared to the positive control (B0F4)

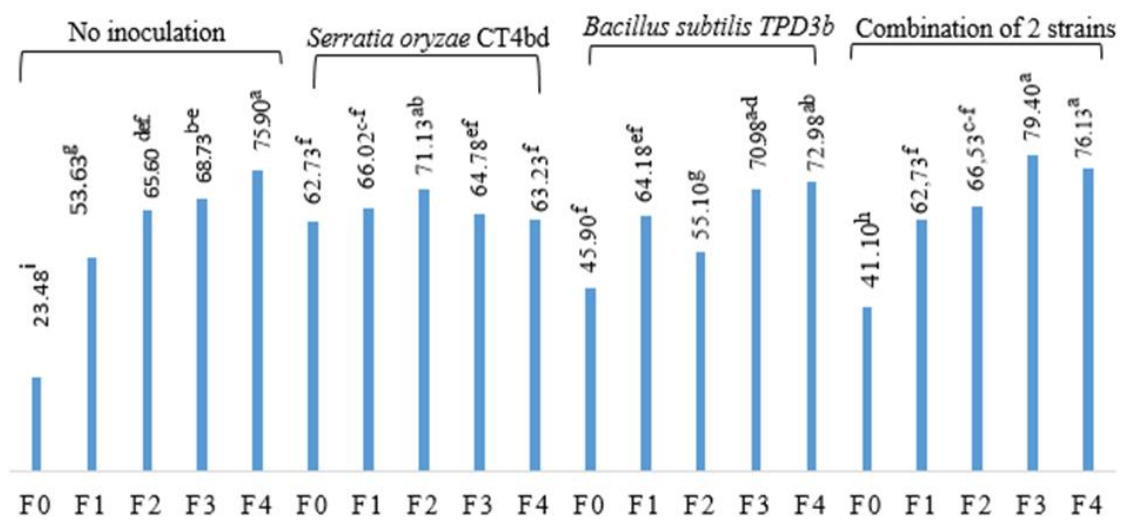

Figure 3 Effects of two strains and nitrogen and phosphorus on stalk yield (ton / ha) of sugarcane (K95-156 cultivar) cultivated on Acrisols in the pot experiment

Numbers following the same word not difference at $5 \%$ level 


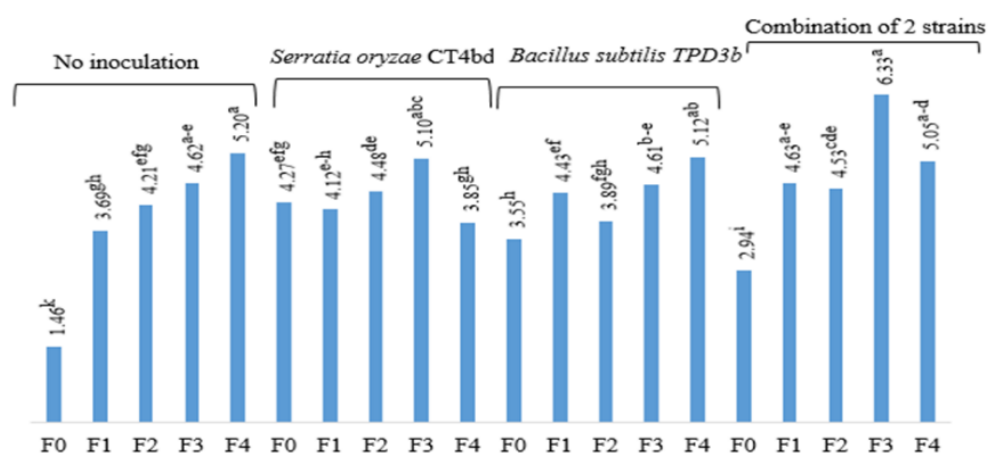

Figure 4 Effects of two strains and nitrogen and phosphorus on sugar yield (ton /ha) of sugarcane (K95-156 cultivar) cultivated on Acrisols in the pot experiment

$$
(\mathrm{F} 0=0 \mathrm{NP}, \mathrm{F} 1=25 \% \mathrm{NP}, \mathrm{F} 2=50 \% \mathrm{NP}, \mathrm{F} 3=75 \% \mathrm{NP}, \mathrm{F} 4=100 \% \mathrm{NP})
$$

Numbers following the same word not difference at $5 \%$ level

From results of regression analysis of between stalk yield and plant height, diameter of stem and CCS (Table 3), $\mathrm{R}^{2}$ of each pair analysis were $0.5098,0.4421,0.6808$ and 0.8769 respectively. These results showed that plant height, diameter of stem and CCS had close correlation to stalk yield. Positive effectiveness of the two bacteria strains on plant height, diameter of stem enhanced stalk yield and then, sugar yield of sugarcane.

Table 3 The relationship between stalk yield with yield component, internode number and Sugar yield.

\begin{tabular}{|l|l|l|l|}
\hline \multirow{4}{*}{ Stalk yield } & Plant height & $\mathrm{y}=0.7218 \mathrm{x}+39.223$ & $\mathrm{R}^{2}=0.5098$ \\
\cline { 2 - 4 } & Stem diameter & $\mathrm{y}=0.0083 \mathrm{x}+1.7782$ & $\mathrm{R}^{2}=0.4421$ \\
\cline { 2 - 4 } & $\mathrm{N}^{0}$ of internodes & $\mathrm{y}=0.0774 \mathrm{x}+6.6237$ & $\mathrm{R}^{2}=0.6808$ \\
\cline { 2 - 4 } & Sugar yield & $\mathrm{y}=0.0692 \mathrm{x}-0.024$ & $\mathrm{R}^{2}=0.8769$ \\
\hline
\end{tabular}

In experiments evaluating the in vitro plant growth promoting effects, the interaction between plant growth promoting bacteria and plants was influenced by a number of factors, including the interaction of bacterial strains used in combination needed to be considered. In the study of Govindarajan [13], the combination of strain Burkholderia vietnamiensis MG43 with Gluconacetobacter diazotrophicus and Herbaspirillum seropedicae gave a lower efficiency in cane yield compared to the treatment using only Burkholderia vietnamiensis MG43 in the sugarcane pot trial.

For the interaction of bacteria and chemical fertilizers, the increase in the chemical fertilizer content was not always positively correlated with the expected efficiency on the crop. Through Table 5 and Figure 6, the treatment using the combination of two bacteria strains CT4bd and TPD3b with 100\% of chemical N, P fertilizers reduced degree Brix, CCS and sugar yield compared to treatment using 75\% N, P fertilizers. This trend was also reported by Suman [14] when studying the plant growth-promoting effects of 7 Gluconacetobacter diazotrophicus strains on sugarcane varieties CoSe92423 grown under greenhouse conditions. At the rate of $75 \mathrm{~kg} \mathrm{~N} /$ ha fertilizer, all 7 strains used individually increased dry matter weight from 18.3 to $79.86 \%$ compared with negative control without using bacteria. However, at the rate of $150 \mathrm{~kg} \mathrm{~N} /$ ha fertilizer, only 3 out of the 7 isolates increased dry matter weight from 21.28 to $25.44 \%$, lower increases compared with the rate of $75 \mathrm{~kg} \mathrm{~N} /$ ha fertilizer.

Through the pot experiment results, following trends can be drawn: (1) In the absence of using chemical N, P fertilizers, both strains of bacteria had good effects on all parameters compared to the treatment without using bacteria. (2) The fertilization level of $25 \% \mathrm{~N}$ and $\mathrm{P}$ fertilizers in combination with bacteria did not have a significant effect on the growth and yield of sugarcane, so these treatments were reduced in the field experiment later. (3) CT4bd strain, when used in combination with N, P fertilizer, increased stem diameter, degree Brix and commercial cane sugar. (4) The TPD3b isolate when used in combination with $\mathrm{N}$, P fertilizer increased the number of internodes, degree Brix and commercial cane sugar. (5) The treatments used 2 bacterial strains in combination with $75 \% \mathrm{~N}$ and $\mathrm{P}$ fertilizers had the best effect on all monitoring criteria. 
Thus, two strains CT4bd and TPD3b were continuously studied for the effect on growth and yield of sugarcane variety K95-156 in combination with chemical fertilizers $\mathrm{N}$ and $\mathrm{P}$ at $0 \%, 50 \%, 75 \%$ and $100 \%$ field scale.

\subsection{Field experiment}

Regarding the growth criteria, the treatments using bacteria and $75-100 \%$ of $\mathrm{N}$, P fertilizers all showed higher results than or equal to the positive control (B0F3) (Table 4). CT4bd combined with 75\% N, P fertilizer (B1F2) increased 15.2\% internodes. Similarly, the results of using TPD3b alone or the combination of two strains at $75 \%$ rate of N, P fertilizers (B2F2 and B3F2) increased the number of internodes from 4.2 to $8.4 \%$. The combination of two strains at $75 \% \mathrm{~N}, \mathrm{P}$ fertilizers (B3F2) caused stalk height, similar to the positive control $(241.55 \mathrm{~cm}$ compared $235.30 \mathrm{~cm})$.

Table 4 Effects of two strains and nitrogen and phosphorus fertilizers on plant height (cm) and number of internodes/plant of sugarcane (K95-156 cultivar) cultivated on Acrisols in the field experiment

\begin{tabular}{|c|c|c|}
\hline Treatment & $\begin{array}{l}\text { Plant } \\
\text { height }(\mathrm{cm})\end{array}$ & $\begin{array}{l}\text { Number of internodes } \\
\text { / plant }\end{array}$ \\
\hline O N-P no inoculation (B0F0) & $181.30^{\mathrm{f}}$ & $17.80 \mathrm{~g}$ \\
\hline $50 \%$ N-P no inoculation (B0F1) & $206.40 \mathrm{cde}$ & $23.55^{b-f}$ \\
\hline 75\% N-P no inoculayion (B0F2) & $209.15 \mathrm{bcd}$ & $24.13^{\mathrm{a}-\mathrm{e}}$ \\
\hline $100 \%$ N-P no inoculation (B0F3) & $235.30^{\mathrm{a}}$ & $24.75^{\mathrm{abc}}$ \\
\hline $0 \mathrm{~N}-\mathrm{P}+$ Serratia oryzae CT4bd (B1F0) & 189.55 ef & 22.45 ef \\
\hline $50 \%$ N-P + Serratia oryzae CT4bd (B1F1) & $222.20 \mathrm{abc}$ & $24.55^{a-d}$ \\
\hline 75\% N-P + Serratia oryzae CT4bd (B1F2) & $223.85^{a b}$ & $25.80^{\mathrm{a}}$ \\
\hline $100 \%$ N-P + Serratia oryzae CT4bd (B1F3) & $234.45^{\mathrm{a}}$ & $27.10^{\mathrm{a}}$ \\
\hline $0 \mathrm{~N}-\mathrm{P}+$ Bacillus subtilis TPD3b CT4bd (B2F0) & $204.60 \mathrm{de}$ & $22.65^{\text {def }}$ \\
\hline $50 \% \mathrm{~N}-\mathrm{P}+$ Bacillus subtilis TPD3b (B2F1) & $203.65^{\mathrm{de}}$ & $25.55^{\mathrm{ab}}$ \\
\hline $75 \% \mathrm{~N}-\mathrm{P}+$ Bacillus subtilis TPD3b (B2F2) & $202.50 \mathrm{~d}_{\mathrm{e}}$ & $24.15^{\mathrm{a}-\mathrm{e}}$ \\
\hline $100 \%$ N-P + Bacillus subtilis TPD3b (B2F3) & $211.20 \mathrm{bcd}$ & $25.80^{\mathrm{a}}$ \\
\hline $0 \mathrm{~N}-\mathrm{P}+$ S. oryzae CT4bd + B. subtilis TPD3b (B3F0) & $212.65 \mathrm{bcd}$ & $21.60^{\mathrm{f}}$ \\
\hline $50 \% \mathrm{~N}-\mathrm{P}+$ S. oryzae CT4bd + B. subtilis TPD3b (B3F1) & $214.00 \mathrm{bcd}$ & $23.10^{c-f}$ \\
\hline 75\% N-P + S. oryzae CT4bd + B. subtilis TPD3b (B3F2) & $241.55^{\mathrm{a}}$ & $26.83^{a}$ \\
\hline $100 \% \mathrm{~N}-\mathrm{P}+$ S. oryzae CT4bd + B. subtilis TPD3b (B3F3) & $247.55^{\mathrm{a}}$ & $27.03^{\mathrm{a}}$ \\
\hline $\mathrm{CV} \%$ & 8.68 & 9.29 \\
\hline
\end{tabular}

Numbers following the same word not difference at $5 \%$ level

For stalk yield (Figure 5), using the CT4bd alone or combination of two strains with 75\% of fertilizer N, P (B1F2, B3F2) gave the similar yield to the positive control (74.19 ton / ha and 72.29 ton / ha compared with 69.38 ton / ha. The difference was not statistically significant at the level of $\alpha=0.05)$. Thus, CT4bd isolate or a combination of CT4bd and TPD3b had similar efficiency to $25 \%$ of chemical N, P fertilizer on stalk yield of variety K95-156 after 12 months of yield trial. 


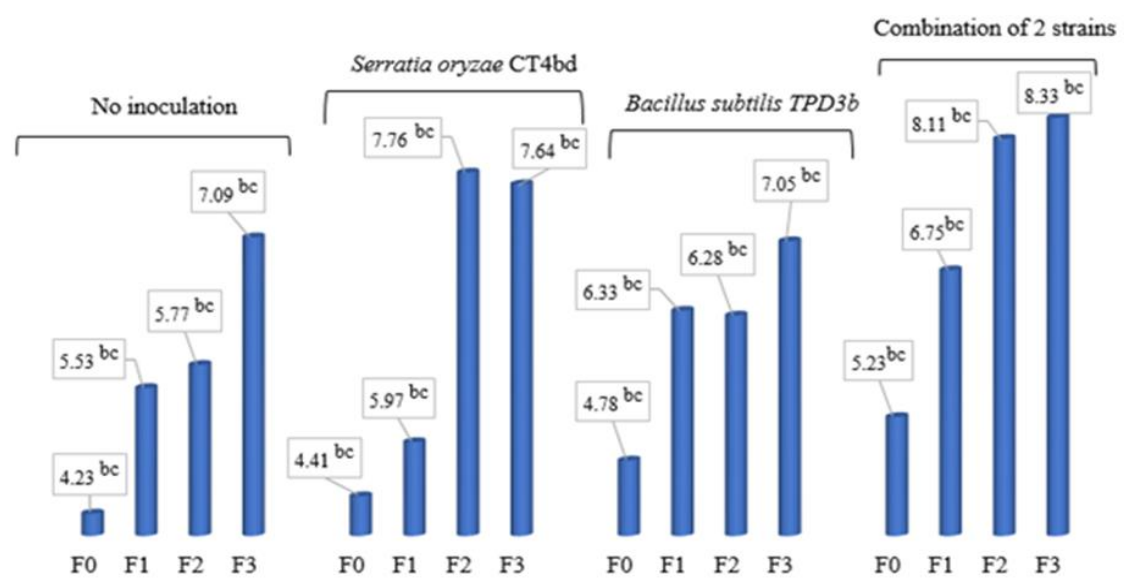

Figure 5 Effects of two strains and nitrogen and phosphorus fertilizers on stalk (cane) yield (ton / ha) of sugarcane

(K95-156 cultivar) cultivated on Acrisols in the pot experiment.

(F0 $=0$ NP. F1 $=50 \%$ NP. F2 $=75 \%$ NP. F3 $=100 \%$ NP)

Numbers following the same word not difference at $5 \%$ level

For the degree Brix, CCS and sugar yield (Table 5 and Figure 6), the treatments using bacteria and 100\% N, P fertilizers were more effective than the positive control. Treatments B1F3, B2F3 and B3F3 all reached the degree Brix of 22.08\%, $22.30 \%$ and $22.47 \%$ respectively, compared to $20.78 \%$ of the positive control. These meant increases in the degree Brix about $1.4 \%-8.1 \%$. This trend was also observed in case of CCS. When CT4bd and TPD3b were used separately or together with $100 \% \mathrm{~N}$, P fertilizers, their CCSs achieved by $10.98 \%, 11.07 \%$ and $11.33 \%$ respectively compared with the positive control' CCS about $10.22 \%$. The rate of increase in CCSs of the three above mentioned treatments reached $7.4 \%, 8.3 \%$ and $10.9 \%$ respectively.

Table 5 Effects of two strains and nitrogen and phosphorus fertilizers on degree Brix (\%) and CCS (\%) of sugarcane (K95-156 cultivar) cultivated on Acrisols in the field experiment

\begin{tabular}{|c|c|c|}
\hline Treatment & Degree Brix (\%) & $\operatorname{CCS}(\%)$ \\
\hline O N-P no inoculation (B0F0) & $18.39^{\mathrm{f}}$ & $8.64^{\mathrm{f}}$ \\
\hline $50 \%$ N-P no inoculation (B0F1) & $19.95^{\text {cde }}$ & $9.66 \mathrm{cde}$ \\
\hline 75\% N-P no inoculayion (B0F2) & 20.49 bc & $10.02 \mathrm{bc}$ \\
\hline $100 \%$ N-P no inoculation (B0F3) & $20.78^{b c}$ & $10.22 \mathrm{bc}$ \\
\hline $0 \mathrm{~N}-\mathrm{P}+$ Serratia oryzae CT4bd (B1F0) & $18.38^{\mathrm{f}}$ & $8.63^{f}$ \\
\hline $50 \%$ N-P + Serratia oryzae CT4bd (B1F1) & $20.2^{b c d}$ & $9.83 \mathrm{bcd}$ \\
\hline 75\% N-P + Serratia oryzae CT4bd (B1F2) & $21.19^{a b}$ & $10.48^{a b}$ \\
\hline $100 \%$ N-P + Serratia oryzae CT4bd (B1F3) & $22.08^{a}$ & $11.07^{\mathrm{a}}$ \\
\hline $0 \mathrm{~N}-\mathrm{P}+$ Bacillus subtilis TPD3b CT4bd (B2F0) & $19.32^{\mathrm{def}}$ & $9.25 \mathrm{def}$ \\
\hline $50 \%$ N-P + Bacillus subtilis TPD3b (B2F1) & $20.55^{b c}$ & $10.06^{b c}$ \\
\hline 75\% N-P + Bacillus subtilis TPD3b (B2F2) & $20.01^{\text {cde }}$ & 9.71 cde \\
\hline $100 \%$ N-P + Bacillus subtilis TPD3b (B2F3) & $21.94^{\mathrm{a}}$ & $10.98^{\mathrm{a}}$ \\
\hline $0 \mathrm{~N}-\mathrm{P}+$ S. oryzae CT4bd + B. subtilis TPD3b (B3F0) & 19.07 ef & $9.09 \mathrm{df}$ \\
\hline $50 \% \mathrm{~N}-\mathrm{P}+$ S. oryzae CT4bd + B. subtilis TPD3b (B3F1) & $21.14^{\mathrm{ab}}$ & $10.45^{a b}$ \\
\hline 75\% N-P + S. oryzae CT4bd + B. subtilis TPD3b (B3F2) & $22.30^{\mathrm{a}}$ & $11.22^{\mathrm{a}}$ \\
\hline $100 \% \mathrm{~N}-\mathrm{P}+$ S. oryzae CT4bd +B. subtilis TPD3b (B3F3) & $22.47^{\mathrm{a}}$ & $11.33^{\mathrm{a}}$ \\
\hline CV \% & 5.75 & 7.15 \\
\hline
\end{tabular}


In particular, for the sugar yield, B1F2 (Figure 6), the treatment of bacteria CT4bd combined with 75\% of N, P fertilizers achieved the yield of 7.76 ton / ha while the positive control B0F3 just reached 7.09 ton / ha, caused an increase about 9.4\% in the sugar yield (Figure 6). The use of a combination of two bacterial strains with 75\% fertilizer N, P (B3F2) showed similar result (8.11 ton / ha) to the result of using TPD3b alone with $100 \% \mathrm{~N}$, P fertilizers (Figure 6). Thus, for sugar yield, the CT4bd or the combination of CT4bd and TPD3b had efficiency equal to 25\% of chemical N, P fertilizes for the sugarcane variety K95-156 after 12 months of the field experiment.

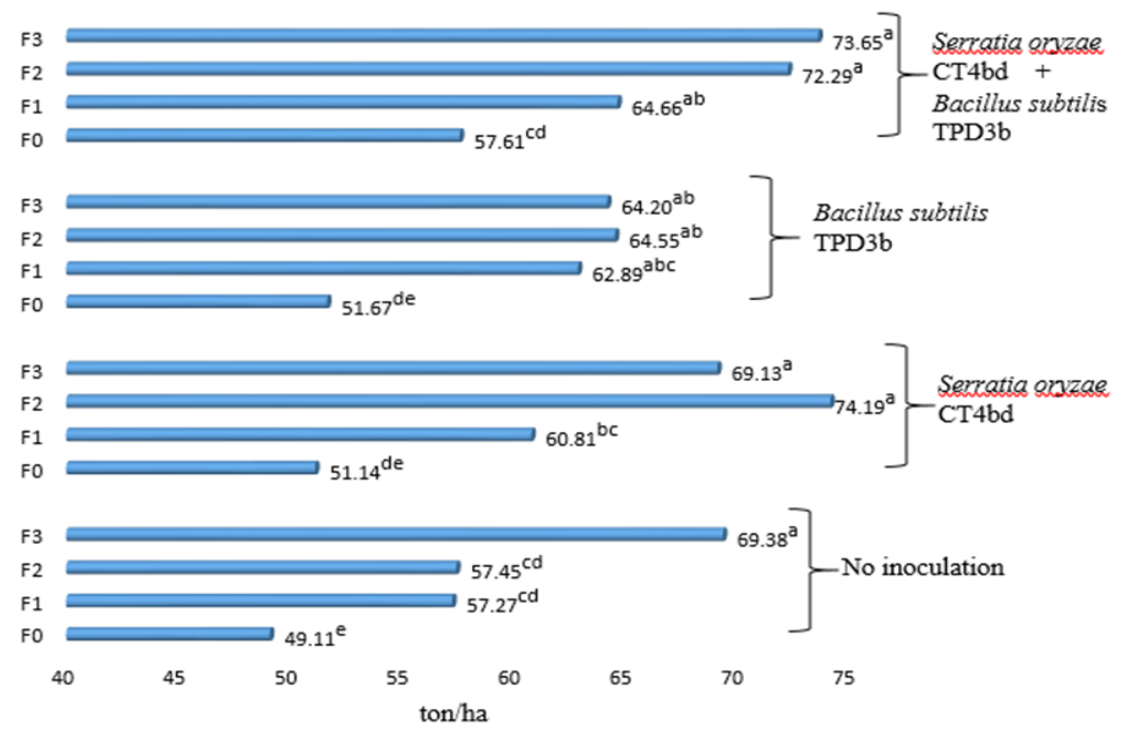

Figure 6 Effects of two strains and nitrogen and phosphorus fertilizers on sugar yield (ton / ha) of sugarcane (K95156 cultivar) cultivated on Acrisols in the field experiment

(F0 $=0$ NP. F1 $=50 \%$ NP. F2 $=75 \%$ NP. F3 $=100 \%$ NP)

Numbers following the same word not difference at $5 \%$ level

Table 6 presented results of regression analysis of between stalk yield and plant height, degree Brix, CCS and sugar yield. $\mathrm{R}^{2}$ of each pair analysis were $0.7361,0.7735,0.7744$ and 0.9588 respectively. These results showed that plant height, degree Brix, CCS and sugar yield had close correlation to stalk yield. Positive effects of the two bacteria strains on plant height, degree Brix, CCS enhanced stalk yield and then sugar yield of sugarcane.

Table 6 The relationship between stalk yield (ton/ha) with yield component and sugar yield (ton/ha) in the field experiment

\begin{tabular}{|l|l|l|l|}
\hline \multirow{4}{*}{ Stalk yield } & Plant height & $\mathrm{Y}=1.9508 \mathrm{x}+93.067$ & $\mathrm{R}^{2}=0.7361$ \\
\cline { 2 - 4 } & N. internodes/plant & $\mathrm{y}=0.1949 \mathrm{x}+10.553$ & $\mathrm{R}^{2}=0.0577$ \\
\cline { 2 - 4 } & Degree Brix & $\mathrm{y}=0.1434 \mathrm{x}+11.552$ & $\mathrm{R}^{2}=0.7735$ \\
\cline { 2 - 4 } & CCS & $\mathrm{y}=0.0947 \mathrm{x}+4.124$ & $\mathrm{R}^{2}=0.7744$ \\
\cline { 2 - 3 } & Sugar yield & $\mathrm{y}=0.1576 \mathrm{x}-3.5196$ & $\mathrm{R}^{2}=0.9588$ \\
\hline
\end{tabular}

Several studies on sugarcane have shown that the use of individual strains or combinations of bacteria has different effects, similar to those observed in the pots experiment. Results of the field experiment [13] showed that strain of Burkholderia vietnamiensis MG43, when combined with the fertilization level of $140 \mathrm{~kg} \mathrm{~N} /$ ha, increased sugarcane yield by about 19-20\%. Meanwhile, the use of Gluconacetobacter diazotrophicus ATCC49037 alone only increased yield by about 13-16\%; Herbaspirillum ATCC35892 increased only about 12\%; and the combination of all 3 strains increased only $14 \%$ at the same fertilizations level. Another trial by Chauhan [15] also showed that the re-inoculation of endophytic bacteria to host sugarcane increased plant weight, plant height and total $\mathrm{N}$ content. In which, sugarcane yield increased by $40 \%$ when inoculated with Bacillus sp. H15 and by $42 \%$ when inoculated with commercial Gluconacetobacter diazotrophicus. 
In addition to the sugarcane variety factor and the interaction of the bacterial strains, the age characteristics of sugarcane shown through plant-cane and ratoon crops also had influence on stalk yield and the yield components. The study of Schultz [4] on the cane variety RB72454 showed that in plant-cane crop and the first ratoon crop, the inoculation of bacteria achieved stem yield similar to that at fertilization level of $120 \mathrm{~kg} /$ ha (positive control). However, in the second ratoon crop, the stalk yield of the treatments with bacterial cultures was less than that of the positive control although the dry matter weight was similar to that in the plant-cane crop and the first ratoon crop.

The field experiment results indicated that for the sugarcane variety K95-156 grown on gray soil in Tay Ninh province, both bacterial strains CT4bd (Serratia oryzae) and TPD3b (Bacillus subtilis) had capacities of promoting plant growth under field condition and could be summarized as following: (1) The strain CT4bd combined with 75 - 100\% N, P fertilizers had good performance on internode number, cane yield, degree Brix , CCS and sugar yield; (2) The strain TPD3b combined with $75-100 \%$ of N, P fertilizers had good effects on parameters including internode number, degree Brix and CCS; (3) The combination of 2 strains CT4bd and TPD3b combined with 75\% of N, P fertilizers had good effects on indicators of internode index, Brix degree, sugar content and actual sugar yield.

Thus, the best treatment proposed for larger scale experiment was the combination of two strains CT4bd and TPD3b combined with $75 \% \mathrm{~N}$, P fertilizers. This experiment saved $25 \%$ of chemical N, P fertilizers and increased $8.4 \%$ in the internode number; $7.3 \%$ in degree Brix; $9.8 \%$ in CCS; and $14.4 \%$ in sugar yield

\section{Conclusion}

Comnination of two strains endophytic Serratia oryzae CT4bd and rihzopheric Bacillus subtilis TPD3b supported sugarcane cultivated on Acrisols of Tay Ninh province, Vietnam. They enhanced sugar yield by $14.4 \%$ (1.02 ton / ha) and saved 25\% inorganic $\mathrm{N}$ and $\mathrm{P}$ fertilizers. These two potential strains were proposed to be tested their ability to promote plant growth on many different sugarcane varieties in both plant-cane and ratoon crops in different material sugarcane areas of Tay Ninh province, Vietnam.

\section{Compliance with ethical standards}

\section{Acknowledgments}

The authors wish to thank the sponsorship of Saigon University, the support of Biotechnology Research and Development of Can Tho University and Thanh Thanh Cong Sugarcane Research and Development Center.

\section{Disclosure of conflict of interest}

There is no conflict of interest

\section{References}

[1] Cruz C, Bird C, Isulat M. Sprouting. survival and growth of young sugarcane (Saccharum officinarum L.) treated with diazotrophic bacteria (Gluconacetobacter diazotrophicus). Philippine Agricultural Scientist. 2012; 95: 106111.

[2] Arthee R, Marimuthu P. Studies on endophytic Burkholderia sp. from sugarcane and its screening for plant growth promoting potential. Journal of Experimental Biology and Agricultural Sciences. 2017; 5(2): 242-257.

[3] Robinson N. Brackin R. Vinall K. Soper F. Holst J. Gamage H. Paungfoo-Lonhienne C. Rennenberg H. Lakshmanan P, Schmidt S. Nitrate paradigm does not hold up for sugarcane. PLoS ONE. 2011; 6: e19045.

[4] Schultz N, da Silva AJ, Sousa JS, Monteiro RC, Oliveira RP, Chaves VA, Pereira W, da Silva MF, Baldani JI, Boddey RM, Reis VM, Urquiaga S. Inoculation of sugarcane with diazotrophic bacteria. R. Bras. Ci. Solo. 2014; 38: 407-414.

[5] Ferrara FIS, Oliveira ZM, Gonzales HHS, Floh EIS, Barbosa HR. Endophytic and rhizospheric Enterobacteria isolated from sugar cane have different potentials for producing plant growth-promoting substances. Plant soil. 2012; 353: 409-417.

[6] Taulé C, Mareque C, Barlocco C, Hackembruch F, Reis VM, Sicardi M, Battistoni F. The contribution of nitrogen fixation to sugarcane (Saccharum officinarum L.) and the identification and characterization of part of the associated diazotrophic bacterial community. Plant soil. 2012; 356: 35-49. 
[7] Lalande R, Bissonnette N, Coutlée D, Antoun H. Identification of rhizobacteria from maize and determination of their plant-growth promoting potential. Plant Soil. 1989; 115: 7-11.

[8] Hoang MT, Cao ND. Isolation and Identification of Rhizospheric Bacteria in Sugarcane (Saccharum spp. L.) Cultivated on Acrisols of Tay Ninh Province, Vietnam. International Journal of Innovations in Engineering and Technology (IJIET). 2017; 8(2): 323-335.

[9] Hoang MT, Cao ND. Isolation and characterization of endophytic bacteria isolated from the sugarcane cultivated on Acrisols of Tay Ninh province,Vietnam. International Journal of Innovations in Engineering and Technology (IJIET). 2017; 8(3): 222-236.

[10] Hoang MT, Dang TNT, Cao ND. Functional and molecular characterization of plant growth promoting bacteria associated with sugarcane cultivated in Tay Ninh Province. Vietnam. Biological and Pharmaceutical Sciences. 2020; 11(02): 265-277.

[11] Ventorino V, Ionata E, Birolo L, Montella S, Marcolongo L, de Chiaro A, Espresso F, Faraco V, Pepe O. Lignocellulose-Adapted Endo-Cellulase Producing Streptomyces Strains for Bioconversion of Cellulose-Based Materials. Frontiers in Microbiology. 2016; 7: 1-15.

[12] Gomez AA, Gomez KA. Statistical Procedures for Agricultural Research. New York: John Wiley and Sons. Ink; 1984.

[13] Govindarajan M, Balandreau J, Muthukumarasamy R, Revathi G, Lakshminarasimhan C. Improved yield of micropropagated sugarcane following inoculation by endophytic Burkholderia vietnamiensis. Plant and Soil. 2006; 280(1): 239-252.

[14] Suman A, Gaur A, Shrivastava AK, Yadav RL. Improving sugarcane growth and nutrient uptake by inoculating Gluconacetobacter diazotrophicus. Plant Growth Regulation. 2005; 47: 155-162.

[15] Chauhan A, Shirkot CK, Kaushal R, Rao DLN. Plant Growth-Promoting Rhizobacteria of Medicinal Plants in NW Himalayas: Current Status and Future Prospects. In Egamberdieva D, Shrivastava S and Varma A. (Eds.), PlantGrowth-Promoting Rhizobacteria (PGPR) and Medicinal Plants. Springer International Publishing. 2015; 381412. 